Editorial

\title{
Inclusive Universities in a Globalized World
}

\author{
Liudvika Leišytè $^{1, *}$, Rosemary Deem ${ }^{2}$ and Charikleia Tzanakou ${ }^{3}$ \\ ${ }^{1}$ Centre for Higher Education, TU Dortmund, Germany; E-Mail: liudvika.leisyte@tu-dortmund.de \\ 2 School of Business \& Management, Royal Holloway, University of London, UK; E-Mail: r.deem@rhul.ac.uk \\ ${ }^{3}$ Centre for Diversity Policy and Research Practice, Oxford Brookes University, UK; E-Mail: ctzanakou@brookes.ac.uk \\ * Corresponding author
}

Submitted: 28 June 2021 | Published: 21 July 2021

\begin{abstract}
This thematic issue of Social Inclusion focuses on universities as inclusive organisations in a variety of different countries and higher education (HE) systems. It explores how these institutions aim, succeed or fail to become inclusive organisations, what policies and processes help achieve these goals and how academics and students can become agents of change through inclusive teaching and research cultures. The contributions in this thematic issue point to the multi-level as well as multi-faceted challenges and characteristics of inclusion in HE in general and in universities in particular, based on both student and academic points of view. They offer innovative conceptual ways of thinking as well as measuring inclusion. Further, they point out the importance of context in understanding the challenges of achieving equality and inclusion in universities through country-specific as well as cross-country comparisons of various aspects of diversity and inclusivity. We hope this thematic issue will inspire theoretical thinking, support practitioners and encourage policy-making about more responsible ways of defining and fostering inclusive universities in a globalised world.
\end{abstract}

\section{Keywords}

academic staff; diversity; higher education; inclusive university; students

\section{Issue}

This editorial is part of the issue "Inclusive Universities in a Globalized World" edited by Liudvika Leišyte (TU Dortmund, Germany), Rosemary Deem (Royal Holloway, UK) and Charikleia Tzanakou (Oxford Brookes University, UK).

(C) 2021 by the authors; licensee Cogitatio (Lisbon, Portugal). This editorial is licensed under a Creative Commons Attribution 4.0 International License (CC BY).

\section{Introduction and Context}

This thematic issue of Social Inclusion focuses on universities as inclusive organisations in a variety of different countries and higher education (HE) systems. Why did we choose this theme? In the context of the UN Sustainable Development Goals, growing inequalities in the world (Lamont et al., 2016), as well as the increasing digitalisation of our societies, the idea of an inclusive university becomes more pertinent. However, we know comparatively little about what an inclusive university means, what characteristics it has and what role it plays in a globalised society (Powell \& Pfahl, 2018; Stewart \& Valian, 2018).

Models of universities such as the world-class university and entrepreneurial university have permeated $\mathrm{HE}$ discourses and practices (Clark, 1998; Deem et al., 2008;
Etzkowitz \& Zhou, 2008; Marginson, 2017). Other studies have explored diversity management approaches in universities (Plummer, 2003). However, there has been little in-depth investigation of what is meant and what role is played by an inclusive university where various types of diversity are celebrated and supported without discrimination or stigmatisation, enabling opportunities for all. Who is included makes a difference too, as recent studies of black and ethnic minority students in countries like South Africa reveal, with high student fees and colonial curricula causing many problems (Ashwin \& Case, 2018). Furthermore, studying inclusion in HE should refer to both students and staff.

There is an atomisation of studies dealing with various aspects of diversity and discrimination in HE. Studies exploring various aspects of diversity usually focus on one aspect, like gender or race (Bhopal, 2016; 
Leišytė \& Hosch-Dayican, 2014; Morley \& Crossouard, 2016; van den Brink \& Benschop, 2014; Winchester \& Browning, 2015), although intersectionality is increasingly discussed in gender studies (Deem, 2018a). There has also been little research in relation to why funded comparative project outcomes aimed at reducing forms of inequality in $\mathrm{HE}$ are not sustained in the longer term (Deem, 2018b) and why policies and efforts to promote gender equality do not always lead to the intended effects (Leišytè, 2019; Tzanakou, 2019; Tzanakou \& Pearce, 2019).

Another focus is about migrant and refugee students' access to $\mathrm{HE}$ and their degree outcomes (Jungblut \& Pietliewicz, 2017). Such research has also drawn more attention to ethnicity and race (Arday \& Mirza, 2018). Increasingly, intersectionality literature has pointed out the complexity of which combination of groups are included or excluded from HE. Disability studies have also emphasised approaches such as Universal Design of Education at universities (Powell \& Pfahl, 2018).

The focus of some studies has included both HE students and staff. Nonetheless, they are limited to undergraduate students (rather than masters or doctoral candidates) or academic staff (rather than administrative staff). Studies about migrant students, disabled staff, students and staff from different religious groups, LGBTQ staff and students and students from disadvantaged socioeconomic backgrounds have been slower to emerge.

What does it mean to be an inclusive university? There is no widely accepted definition of inclusion in HE (Krischler et al., 2019). The university has traditionally been an institution for the elites-an 'ivory tower.' In the context of massification and universal $\mathrm{HE}$, universities have been redefined as needing to be more inclusive. At the same time, the pressures for institutional positioning and competition via rankings have reproduced elitism in the form of flagship research universities versus universities of applied sciences or community colleges (Mergner et al., 2019). Nevertheless, technological developments, like digitalisation, big data, and artificial intelligence, potentially enable us to consider overcoming some types of exclusion in a university environment, even if simultaneously creating ethical issues and schisms among students and staff (Rubel \& Jones, 2016).

This thematic issue focuses especially on universities as organisations and how they aim, succeed or fail to become inclusive organisations, what policies and processes help achieve these goals and how academics and students can become agents of change through inclusive teaching and research cultures.

\section{Overview of Contributions}

The thematic issue offers interesting conceptual lenses for studying inclusion in HE. McArthur (2021) drawing on a critical theory approach and using a plural notion of recognition, argues that change towards an inclusive university should go beyond individual activities and focus on groups and identities and embrace holistic and transformative change. Based on empirical evidence from the UK, Wren Butler (2021) proposes the framework of legibility zones, highlighting the complex dynamics of unbelonging in $\mathrm{HE}$ to better understand the challenges that universities face in their inclusion projects. In his commentary, Thompson (2021) argues that universities need to be proactive in ensuring that they become fully and meaningfully inclusive to play their part in addressing the challenges posed by the need for global sustainable development.

Two contributions in this thematic issue discuss inclusion in $\mathrm{HE}$ at the macro level from a comparative perspective, drawing on the workings of policies as well as indicators that are helpful to understand inclusion in $\mathrm{HE}$ in a holistic way. Kamanzi et al. (2021) analyse the role of public policies in supporting or failing to support more inclusive access to and experience of university in different massified HE systems. Policy areas explored include guidance systems and educational pathways, status-driven stratification of institutions, hierarchies of disciplinary fields and the financing of $\mathrm{HE}$, including tuition fees where these exist. Meanwhile, Veidemane et al. (2021) examine how the progress of inclusive $\mathrm{HE}$ can be measured and assessed across different universities and $\mathrm{HE}$ systems. They consider which indicators are the most relevant and helpful in a comparative context.

Articles drawing on comparative research designs and country-specific contexts report not only student and academic staff perspectives on inclusivity, but also reveal to what extent academic career systems can be more or less inclusive. Resch and Amorim (2021) explore different formats of intercultural student encounters among international and local students across six European countries. Their study shows that formats embedded in the curriculum are most suited to facilitating social network formation, whereas extracurricular formats tend to be single occasion activities, without follow-up. Pietilä et al. (2021), drawing on national statistical data about Nordic universities' academic and research staff, show national differences across Sweden, Norway and Finland with a focus on gender and country of origin, contributing to discussions about gendered patterns of global academia and social stratification in Nordic universities.

In specific country contexts, we draw attention to studies based in Spain, Germany and the Czech Republic. From the students' point of view, Gallego-Noche et al. (2021) show that Spanish university students experience discrimination particularly based on religion, age, sex and political ideology, with linguistic minorities, ideology and migration background standing out as the strongest predictors. Spanish academics seem to hold rather homogeneous views regarding diversity and inclusion in $\mathrm{HE}$ as shown by Pérez-Carbonell et al. (2021). In another study, Mora et al. (2021) point out that the academic staff studied drew on wide definitions of inclusivity beyond cognition, using Universal Design of Learning principles, and 
were supportive of working with heterogeneous groups, using cooperative methodologies to promote solidarity and group cohesion and having systematic policies at institutional level.

In the German HE context, Wilkens et al. (2021) explore the contribution that digitalisation can make to the accessibility of HE programmes, particularly for those who have a disability or experience mental health problems. The study showed that accessible digital tools and inclusion-sensitive pedagogy were both vital for equal participation in $\mathrm{HE}$ at a case study university in Germany. Grüttner et al. (2021) draw on a survey of students and interviews with staff in German HE institutions, pointing out the challenges experienced by the refugee students in transition to $\mathrm{HE}$ in preparatory programmes.

Unangst and Martínez Alemán (2021) study the extent to which the German HE system is tackling its colonial past in the curriculum, teaching programmes and organisational features of $\mathrm{HE}$ institutions. Yet another contribution from the German HE context, by Bartz and Kleina (2021), shows the importance of diversity training in promoting inclusive learning environments.

Finally, Vohlídalová (2021) examines the casualisation of staff working conditions in the Czech academic labour market, exploring gender, sectoral, and institutional inequalities, using labour market segmentation theory. This article points to the importance of taking into account disciplinary variations when discussing inequalities and inclusion in $\mathrm{HE}$.

\section{Conclusions}

The contributions in this thematic issue point to the multi-level as well as multi-faceted challenges and characteristics of developing and sustaining inclusion in $\mathrm{HE}$ in general and in universities in particular. They offer innovative and conceptual ways of thinking as well as measuring inclusion. Further, they point out the importance of context in understanding the challenges of achieving equality and inclusion in universities. Finally, this thematic issue draws on the views of both students and staff to understand the complexities associated with making universities more inclusive-from admissions policy through curriculum change at programme level to broader organisational development-which helps to get a more holistic picture of what it means to be an inclusive university. We hope this thematic issue will inspire theoretical thinking, practitioner engagement and more sophisticated policy making, in search of more responsible ways of defining and fostering inclusive universities.

\section{Acknowledgments}

The editors would like to thank the anonymous reviewers for their timely and insightful comments, which significantly contributed to the development of the submissions to the thematic issue.

\section{Conflict of Interests}

The authors declare no conflict of interests.

\section{References}

Arday, J., \& Mirza, H. S. (Eds.). (2018). Dismantling race in higher education: Racism, whiteness and decolonising the academy. Palgrave MacMillan.

Ashwin, P., \& Case, J. (Eds.). (2018). Pathways to the public good: Access, experiences and outcomes of South African undergraduate education. African Minds.

Bartz, J., \& Kleina, W. (2021). Diversity is not the enemy: Promoting encounters between university students and newcomers. Social Inclusion, 9(3), 154-164.

Bhopal, K. (2016). The experiences of Black and minority ethnic academics: A comparative study of the unequal academy. Routledge.

Clark, B. R. (1998). Creating entrepreneurial universities: Organizational pathways of transformation. Pergamon.

Deem, R. (2018a). The gender politics of higher education. In B. Cantwell, H. Coates, \& R. King (Eds.), Handbook on the politics of higher education (pp. 431-448). Cheltenham: Edward Elgar.

Deem, R. (2018b). Living with gender in the 21st century university: How do we now effect lasting change? In A. Torres, P. Pinto, \& C. Casimiro (Eds.), Género, direitos humanos e desigualdades [Gender, human rights and inequalities] (pp. 281-301). ISCSP, Universidade de Lisboa.

Deem, R., Ho Mok, K., \& Lucas, L. (2008). Transforming higher education in whose image? Exploring the concept of the 'world-class' university in Europe and Asia. Higher Education Policy, 21(1), 83-97.

Etzkowitz, H., \& Zhou, C. (2008). Introduction to thematic issue: Building the entrepreneurial university: The global perspective. Science and Public Policy, 35(9), 627-635.

Gallego-Noche, B., Goenechea, C., Antolínez-Domínguez, I., \& Valero-Franco, C. (2021). Towards inclusion in Spanish higher education: Understanding the relationship between identification and discrimination. Social Inclusion, 9(3), 81-93.

Grüttner, M., Schröder, S., \& Berg, J. (2021). University applicants from refugee backgrounds and the intention to drop out from pre-study programs: A mixed-methods study. Social Inclusion, 9(3), 130-141.

Jungblut, J., \& Pietliewicz, K. (2017). (Eds.). Refugees welcome? Recognition of qualifications held by refugees and access to higher education in Europe. Country analyses. ESU.

Kamanzi, P. C., Goastellec, G., \& Pelletier, L. (2021). Mass university and social inclusion: The paradoxical effect of public policies. Social Inclusion, 9(3), 32-43.

Krischler, M., Powell, J. J. W., \& Pit-Ten Cate, I. N. (2019). What is meant by inclusion: On the effects 
of different definitions on attitudes toward inclusion. European Journal of Special Needs Education, 34(5), 632-648.

Lamont, M., Silva, G. M., Welburn, J. S., Guetzkow, J., Mizrachi, N., Herzog, H., \& Reis, E. (2016). Getting respect. Responding to stigma and discrimination in the United States, Brazil, and Israel. Princeton University Press.

Leišytė, L. (2019). Gender in European research policy. In D. Simon, S. Kuhlmann, J. Stamm, \& W. Canzler (Eds.), Handbook on science and public policy (pp. 284-315). Edward Elgar.

Leišytė, L., \& Hosch-Dayican, B. (2014). Changing academic roles and shifting gender inequalities: A case analysis of the influence of the teaching-research nexus on the academic career prospects of female academics in The Netherlands. Journal of Workplace Rights, 17(3/4), 467-490.

Marginson, S. (2017). The world-class multiversity: Global commonalities and national characteristics. Frontiers of Education in China, 12(2), 233-260.

McArthur, J. (2021). The inclusive university: A critical theory perspective using a recognition-based approach. Social Inclusion, 9(3), 6-15.

Mergner, J., Leišytè, L., \& Bosse, E. (2019). The widening participation agenda in German higher education: Discourses and legitimizing strategies. Social Inclusion, 7(1), 61-70.

Mora, A. M. M., Chiva, I., \& Lloret-Catala, C. (2021). Faculty perception of inclusion in the university: Concept, policies and educational practices. Social Inclusion, 9(3), 106-116.

Morley, L., \& Crossouard, B. (2016). Gender in the neoliberalised global academy: The affective economy of women and leadership in South Asia. British Journal of Sociology of Education, 37(1), 149-168.

Pérez-Carbonell, A., Ramos-Santana, G., \& MartínezUsarralde, M.-J. (2021). Comparative inclusion: What Spanish higher education teachers assert. Social Inclusion, 9(3), 94-105.

Pietilä, M., Drange, I., Silander, C., \& Vabø, A. (2021). Gender and globalization of academic labor markets: Research and teaching staff at Nordic universities. Social Inclusion, 9(3), 69-80.

Plummer, D. L. (2003). Overview of the field of diversity management. In D. L. Plummer (Ed.), Handbook of diversity management. Beyond awareness to competency-based learning (pp. 1-49). University Press of America.

Powell, J. J. W., \& Pfahl, L. (2018). Disability studies in the universal design university. In S. K. Gertz, B. Huang, \& L. Cyr (Eds.), Diversity and inclusion in higher education and societal contexts: International and interdisciplinary approaches (pp. 157-188). Palgrave Macmillan.

Resch, K., \& Amorim, J. P. (2021). Facilitating intercultural encounters with international students: A contribution to inclusion and social network formation. Social Inclusion, 9(3), 58-68.

Rubel, A., \& Jones, K. M. L. (2016). Student privacy in learning analytics: An information ethics perspective. The Information Society, 32(2), 143-159.

Stewart, A. J., \& Valian, V. (2018). An inclusive academy: Achieving diversity and excellence. MIT Press.

Thompson, S. (2021). The need and desire for inclusive universities: A perspective from development studies. Social Inclusion, 9(3), 27-31.

Tzankou, C. (2019). Unintended consequences of genderequality plans. Nature, 570, 277.

Tzanakou, C., \& Pearce, R. (2019). Moderate feminism within or against the neoliberal university? The example of Athena SWAN. Gender, Work \& Organization, 26(8), 1191-1211.

Unangst, L., \& Martínez Alemán, A. M. (2021). Coloniality in the German higher education system: Implications for policy and institutional practice. Social Inclusion, 9(3), 142-153.

van den Brink, M., \& Benschop, Y. (2014). Gender in academic networking: The role of gatekeepers in professorial recruitment. Journal of Management Studies, 51(3), 460-492.

Veidemane, A., Kaiser, F., \& Craciun, D. (2021). Inclusive Higher Education Access for Underrepresented Groups: It Matters, But How Can Universities Measure It? Social Inclusion, 9(3), 44-57.

Vohlídalová, M. (2021). The segmentation of the academic labour market and gender, field, and institutional inequalities. Social Inclusion, 9(3), 163-174.

Wilkens, L., Haage, A., Lüttmann, F., \& Bühler, C. R. (2021). Digital teaching, inclusion and students' needs: Student perspectives on participation and access in higher education. Social Inclusion, 9(3), 117-129.

Winchester, H. P. M., \& Browning, L. (2015). Gender equality in academia: A critical reflection. Journal of Higher Education Policy and Management, 37(3), 269-281.

Wren Butler, J. (2021). Legibility zones: An empiricallyinformed framework for considering unbelonging and exclusion in contemporary English academia. Social Inclusion, 9(3), 16-26.

\section{About the Authors}

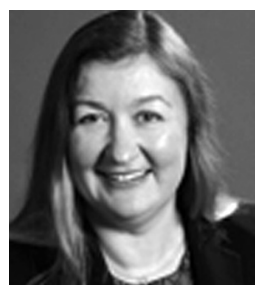

Liudvika Leišytė is Professor of Higher Education and Deputy Director at the Centre for Higher Education at the TU Dortmund, and a visiting senior scholar at the Centre for Higher Education Policy Studies, University of Twente. The recipient of the 2018 Emerald Literati Award for the Highly Commended paper, Professor Leišytè focuses on the nexus of academic work and organisational transformation in higher education, whereby diversity and inclusion in higher education are central for her research and practice. 

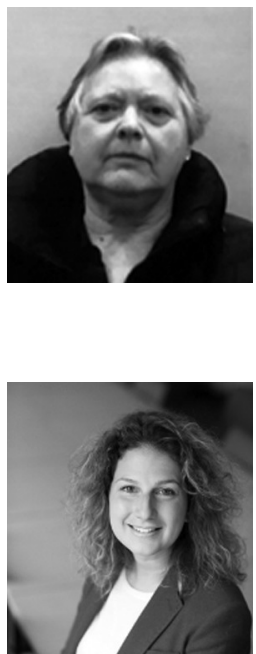

Rosemary Deem is Emerita Professor of HE Management and Doctoral School Senior Research Fellow, Royal Holloway (University of London). She was Dean of History/Social Science in 2009-2011, Vice-Principal Education in 2011-2017, VP Teaching Innovation, Equality/Diversity in 2017-2019, all at Royal Holloway, UK RAE panellist in 1996, 2001 and 2008, and has been part of the College of Review Panel Members at the European Science Foundation since 2017. She is a Fellow of the UK Academy of Social Sciences and co-editor of the journal Higher Education (Springer). She was appointed OBE for services to HE and social sciences in 2013, is co-convenor of the HE Network (European Educational Research Association) and was Chair of the UK Council for Graduate Education 2015-2018.

Charikleia Tzanakou (Charoula, PhD) is VC Senior Research Fellow in the Centre for Diversity Research Policy and Practice at Oxford Brookes University, UK. She is an expert in gender and diversity in organisations with a particular focus on higher education institutions. Charoula is particularly interested in understanding better what works and the unintended consequences of gender and diversity efforts and thus contribute towards developing activities that will not only advance gender equality but will also lead to impactful capacity building resources for HEls across the world. 